\title{
Construction and validation of a long-channel membrane test cell for representative monitoring of performance and characterization of fouling over the length of spiral-wound membrane modules
}

\author{
Nadine Siebdratha, Wei Dinga, Elisabeth Pietscha, Joop Kruithof ${ }^{\mathrm{b}}$, Wolfgang Uhla, ${ }^{\mathrm{a}, \mathrm{w}}$, \\ Johannes Vrouwenvelder ${ }^{\mathrm{b}, \mathrm{d}, \mathrm{e}}$ \\ ${ }^{a}$ Technische Universität Dresden, Chair of Water Supply Engineering, 01062 Dresden, Germany \\ ${ }^{b}$ Wetsus, European Centre of Excellence for Sustainable Water Technology, Oostergoweg 9, 8911 MA Leeuwarden, The Netherlands \\ 'Norwegian Institute for Water Research (NIVA), Gaustadalléen 21, 0349 Oslo, Norway, Tel. +47-40 1066 55; Fax: +47-22 18 52 00; \\ email: wolfgang.uhl@niva.no (W. Uhl) \\ ${ }^{d}$ King Abdullah University of Science and Technology (KAUST), Water Desalination and Reuse Center (WDRC), \\ Division of Biological and Environmental Science and Engineering (BESE), Thuwal 23955-6900, Saudi Arabia \\ ${ }^{e}$ Delft University of Technology, Faculty of Applied Sciences, Department of Biotechnology, Van der Maasweg 9, \\ 2629 HZ Delft, The Netherlands
}

Received 28 February 2017; Accepted 20 June 2017

\section{A B S T R A C T}

A long-channel membrane test cell (LCMTC) with the same length as full-scale elements was developed to simulate performance and fouling in nanofiltration and reverse osmosis spiral-wound membrane modules (SWMs). The transparent LCMTC enabled simultaneous monitoring of SWM performance indicators: feed channel pressure drop, permeate flux and salt passage. Both permeate flux and salt passage were monitored over five sections of the test cell and were related to the amount and composition of the accumulated foulant in these five sections, illustrating the unique features of the test cell. Validation experiments at various feed pressures showed the same flow profile and the same hydraulic behaviour as SWMs used in practice, confirming the representativeness and suitability of the test cell to study SWM operation and fouling. The importance to apply feed spacers matching the flow channel height in test cell systems was demonstrated. Biofouling studies showed that the dosage of a biodegradable substrate to the feed of the LCMTC accelerated the gradual decrease of membrane performance and the accumulation of biomass on the spacer and membrane sheets. The strongest permeate flux decline and the largest amount of accumulated biomass was found in the first $18 \mathrm{~cm}$ of the test cell. The LCMTC showed to be suitable to study the impact of biofilm development and biofouling control strategies under representative conditions for full-scale membrane elements.

Keywords: Feed spacer; RO spiral-wound module; NF; Permeate production; Membrane performance; Biofouling

\section{Introduction}

During operation of reverse osmosis ( $\mathrm{RO}$ ) and nanofiltration (NF) systems, membrane fouling deteriorates system performance, strongly increasing treatment costs $[1,2]$.

* Corresponding author.
The development of fouling is a complex process, impacted by hydrodynamic conditions, chemical composition of the feed water, the membrane module and system design (spacer and membrane type) and operation conditions. The different types of fouling - particulate fouling, scaling, organic fouling and biofouling - can occur simultaneously and influence each other [3-6]. Also, the formation of a concentration polarization $(\mathrm{CP})$ layer is impacted by the hydrodynamic conditions 
in the flow channel [7]. The CP layer influences membrane performance $[3,8,9]$ because an increase in the concentration of organics, nutrients and salts enhances the formation of a fouling layer on the membrane surface. Furthermore, the fouling layer increases the $\mathrm{CP}$ and the osmotic pressure $[3,10]$, causing a decline of membrane performance.

In the feed channel of membrane system spacers influence the flow regime by imposing mixing and increased back diffusion of solutes from the membrane surface into the bulk solution. The use of feed spacers increases mass transfer [11] by reducing the $\mathrm{CP}$ [12], but also enhances the development of fouling in the feed channel [13-16].

In water production with $\mathrm{NF}$ and $\mathrm{RO}$, usually SWMs of $1 \mathrm{~m}$ length are assembled with 4-8 modules in series in one pressure vessel $[17,18]$. In the vessel, the concentrate of each membrane element is the feed of the subsequent element. Due to permeation of the feed water, a decrease of the concentrate flow rate and an increase of the concentration of dissolved substances take place over the length of each membrane element and subsequently over the length of the pressure vessel. As a result, the filtration conditions (flow velocity, $\mathrm{CP}$, osmotic pressure and shear force) [19] change. As fouling is considerably influenced by these conditions, it varies over the length of the modules and in time [18,20,21].

For fouling investigations under laboratory conditions, usually pieces of flat sheet membranes are inserted into membrane test cells. These test cells usually have an effective flow channel length of $10-30 \mathrm{~cm}[9,22,23]$. Some of them were developed for fouling research and thus incorporated special features, such as resistance against high pressure $[24,25]$ or a special visualization window to enable tomographical methods and visual control of tracers [26]. All cells have the possibility to remove the membrane coupon at the end of the experimental run for analysis of the fouling layer.

Studies with test cells of the same length as membrane elements used in practice are limited. Bu-Ali et al. [27] were one of the first to emphasize the importance of investigations over the full membrane length. They connected five $0.45-\mathrm{m}$ long test cells in series to investigate ion retention over the length, with a total membrane length of $2.25 \mathrm{~m}$. Vrouwenvelder et al. [28] developed a 0.9-m long flat sheet membrane test cell ("flat sheet membrane simulator"). Vrouwenvelder et al. [28] emphasized that the hydrodynamics inside the test cell must be comparable with the hydrodynamics in an SWM as they considerably influence fouling. However, in their long flat sheet membrane simulator the hydrodynamics differed from those in the SWM. Mo and Ng [12] pointed out the importance of undisturbed flow over the full length of the membrane element. They developed a 1-m long RO membrane test cell with pressure sensors along its length and permeate collectors for differential permeate analysis. In their work, the $\mathrm{CP}$ development over the length of the test cell was investigated. However, flow field characterization and validation of their LCMTC was not given.

There is a lack of knowledge on the formation of fouling over the length of SWMs and pressure vessels. Most experimental studies on fouling formation over the module length were carried out in full-scale treatment plants with differences in operating conditions and water quality parameters, making it difficult to compare the results of different studies. Also, these studies lack a systematic correlation between the foulant layer composition, membrane performance and feed water composition.

In order to study the impact of the complex conditions varying over the length of full-scale membrane modules or pressure vessels on fouling, long test cells are required [26]. Therefore, a test cell with the length of a full-scale element was developed, enabling representative measurement of all performance indicators impacted by fouling: feed channel pressure drop (FCP), permeate flux (permeability) and salt passage [3,29-31]. Operating the test cell under full-scale process conditions, that is, at high pressures, is possible, as well as direct imaging and non-destructive observation and diagnosis of fouling.

\section{Materials and methods}

\subsection{The long-channel membrane test cell: design considerations}

Fouling is affected by a complex interaction of several process conditions. In order to investigate fouling under well-defined, representative conditions for full-scale applications, the requirements for a long-channel membrane test cell (LCMTC) were defined as:

- Undisturbed flow field in a channel of about $1 \mathrm{~m}$ length.

- Material strength for pressures representative of fullscale RO and NF applications.

- Application of different feed spacers and membranes.

- Visual observation of fouling processes.

- Investigation of the impact of fouling on all performance indicators: FCP, permeability and salt rejection.

- Investigation of relevant fouling parameters spatially distributed over the full length of the test cell.

- Non-invasive investigation of the fouling layer.

A picture of the LCMTC is given in Fig. 1 and the corresponding schematic design is displayed in Fig. 2.

A spiral-wound NF or RO membrane module used in practice has a length of $1.016 \mathrm{~m}$ (equalling 40 inch). The effective membrane length (producing permeate) is $\sim 0.91 \mathrm{~m}$. Membrane elements contain feed spacers to separate the membrane sheets, enabling mixing of the water passing the module. In industry, the feed spacer thickness is usually reported in mil: 1 mil equals $25.4 \mu \mathrm{m}$. A $31 \mathrm{mil}(0.787 \mathrm{~mm})$ thick feed spacer is commonly applied in water treatment applications.

In the LCMTC, the feed solution enters the inner membrane channel (width $40 \mathrm{~mm}$ ), equipped with a feed spacer, and flows through the channel of $0.91 \mathrm{~m}$ length, equalling the permeate producing membrane length of a full scale element. The channel width of $40 \mathrm{~mm}$ is chosen so that the sidewall effects on the flow profile, as well as the curvature of the spiral-wound modules [32] can be neglected. The membrane channel height is based on a spacer thickness of $0.787 \mathrm{~mm}$ (31 mil) and is adjustable to $1.19 \mathrm{~mm}$ (47 mil) by varying the LCMTC sealing thickness. In the presented studies, the channel height was $0.787 \mathrm{~mm}$.

When pressure is applied on the feed side of the test cell, part of the feed solution permeates through the membrane and can be collected via the outlet of five separate permeate segments, equally distributed over the LCMTC length (Fig. 2). Each permeate channel has a height of $0.3 \mathrm{~mm}$ and is 


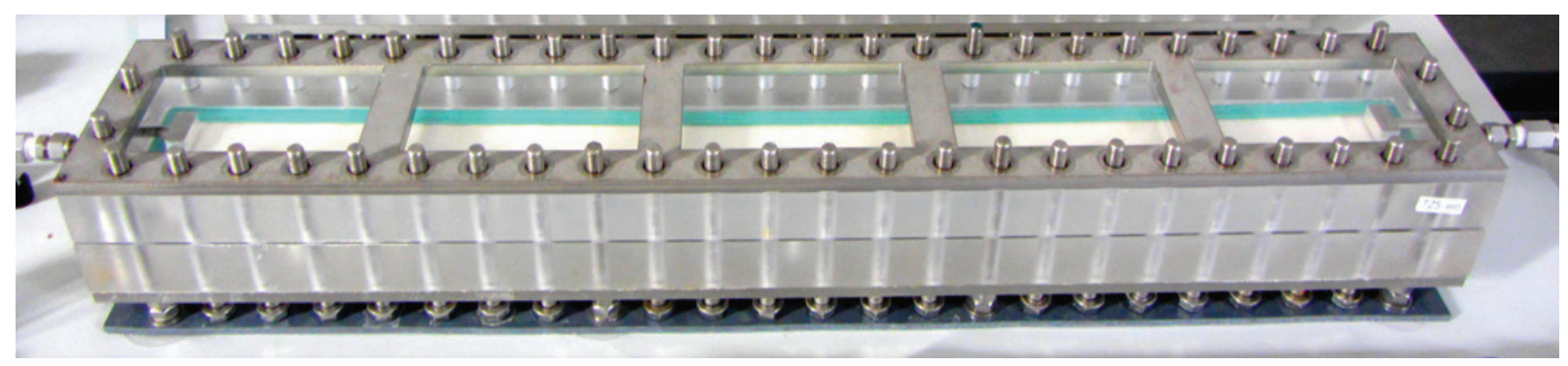

Fig. 1. The long-channel membrane test cell (LCMTC) with the same length as spiral-wound membrane modules (SWMs) used in practice, enabling study of the development of fouling and fouling control strategies in SWMs under representative and controlled conditions.

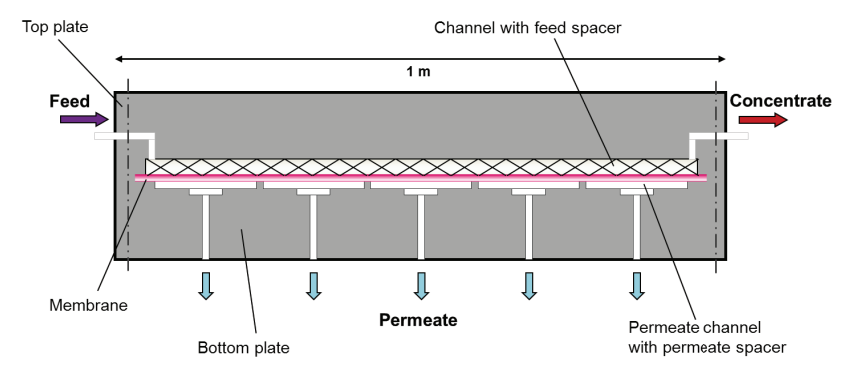

Fig. 2. Schematic representation of the LCMTC with feed spacer and membrane sheets divided into five permeate segments over the test cell length for permeate collection, enabling the assessment of permeability and salt passage and accumulated fouling over the module length of the test cell.

equipped with a permeate spacer of the same thickness. The construction with five separate segments enables the investigation of the FCP, permeate flux and salt passage along the membrane length.

The top lid of the system is made of polymethyl methacrylate (PMMA), allowing visual/microscopic monitoring of the flow distribution and fouling layer. The test cell was constructed to operate up to 40 bar pressure allowing investigations under desalination conditions. Details on the construction design and technical drawings are given in the supplementary material section (Figs. S1-S8, and Tables S1 and S2). When the fouling experiments are completed, the membrane and spacer can be sampled and analysis of the fouling layer accumulated on the membrane and spacer can be performed.

\subsection{Characteristics of the LCMTC in comparison with spiral wound modules}

The effective membrane length of a full-scale SWM (taking into account the glue line of the membrane [33]) was measured in an SWM from Koch Membrane Systems, USA (Fluid Systems ${ }^{\circledR}$ TFC $^{\circledR}-$ FR $4{ }^{\prime \prime \prime}$ Element). The effective (permeate producing) membrane length of the modules of $0.91 \mathrm{~m}$ is applied for the LCMTC. The feed spacer thickness in industrial SWMs ranges between $0.508 \mathrm{~mm}(20 \mathrm{mil})$ and $1.194 \mathrm{~mm}$ (47 mil). Spacers have different characteristics regarding porosity and geometry $[13,34]$. Depending on the salt concentration of the water and applied pressure a permeate flux of $12-45 \mathrm{~L} \mathrm{~m}^{-2} \mathrm{~h}^{-1}$ is used in practice, as well as in the LCMTC. The range of crossflow velocity over the pressure vessel usually varies between $0.2 \mathrm{~m} \mathrm{~s}^{-1}$ at the feed side and $0.07 \mathrm{~m} \mathrm{~s}^{-1}$ at the concentrate side [33]. However, with the test cell higher crossflow velocities up to $0.6 \mathrm{~m} \mathrm{~s}^{-1}$ can be applied. When operating one LCMTC under process conditions representative of practice, a recovery of $4 \%-9 \%$ is achievable, corresponding to approximately $50 \%$ of the recovery of one SWM. This is due to the fact that industrial SWMs have a spacer-filled feed channel enclosed by two membrane sheets, whereas the channel in the test cell is enclosed by one membrane and the PMMA cover (not producing permeate). Table 1 shows that the characteristics of the LCMTC setup are in good agreement with those of SWMs applied in practice.

\subsection{Setup for LCMTC experiments}

The test cell is connected to the setup using stainless steel connectors and pipes (Swagelok, Germany). Two sensitive pressure transmitters (before and after the test cell, IMP 331, ICS Schneider Messtechnik GmbH, Germany) were used for high-resolution transmembrane pressure and FCP measurement. The high pressure membrane metering pump (Hydracell P200, Wanner) was purchased from Verder Deutschland $\mathrm{GmbH}$, Germany. A flow meter (turbine impeller wheel PEL, Kobold Messring, Germany) was installed to measure the feed flow into the system. Temperature measurements were performed with a resistance thermometer PT100, TMH GmbH, Germany. The temperature inside the feed water reservoir was controlled with a heating element connected to a thermostat, Rommelsbacher, Germany. For constant pressure experiments a mechanical pressure relief valve from Swagelok, Germany, was installed. The flow chart of the setup is shown in Fig. 3, for operation of one LCMTC with the setup. In order to conduct experiments simulating the conditions in a pressure vessel, the setup can be extended connecting up to six test cells in series. FCP, permeability and salt passage (as conductivity) can be monitored in time for each cell and for cells operated in series. Process control and data acquisition were performed with the hardware technology TopMessage, Delphin Technology AG, Germany.

\subsection{Validation of the hydraulic behavior}

\subsubsection{Experimental investigation of the flow profile}

In order to determine the flow regime in a spacer-filled channel a concentrated dye Rhodamine B pulse was 
injected into the feed water (tap water) using a syringe shortly before the feed water entered the test cell feed channel. The feed flow velocity was $0.16 \mathrm{~m} \mathrm{~s}^{-1}$. When the dye front entered the visible area of the test cell photographs of the section between 0.4 and $0.6 \mathrm{~m}$ over the flow cell length were taken for evaluation. In this experiment, a spacer (0.787 mm, $31 \mathrm{mil}$ in height and diamond shape) purchased from Hydranautics, USA, was applied. The membrane was taken from a commercial 4" spiral wound module (Koch Membrane Systems, USA, FLUID SYSTEMS ${ }^{\circledR}$ TFC $^{\circledR}$ - FR 4" ELEMENT). Before the study, the membrane system was operated for $12 \mathrm{~h}$ with deionized (DI) water. During the assessment of the flow regime, the test cell was operated without permeate production.

Table 1

Summary of the characteristics of the LCMTC in comparison with SWMs

\begin{tabular}{llll}
\hline Characteristics & LCMTC & $\begin{array}{l}\text { Industrial } \\
\text { SWM }^{\text {a }}\end{array}$ & Reference \\
\hline Active membrane length, $\mathrm{m}^{\mathrm{b}}$ & 0.91 & 0.91 & {$[33]$} \\
Spacer thickness, mil & $31-47$ & $20-47$ & {$[13,34]$} \\
Permeate flux, $\mathrm{L} \mathrm{m}^{-2} \mathrm{~h}^{-1}$ & $12-45$ & $12-45$ & {$[35]$} \\
Feed pressure & $5-40$ & $5-80$ & {$[35]$} \\
Crossflow velocity, $\mathrm{m} \mathrm{s}^{-1}$ & $0.07-0.2$ & $0.07-0.2$ & {$[13]$} \\
Recovery, \% & $4-9$ & $8-18$ & {$[36]$} \\
Salt rejection, \% & 95 to $>99$ & $95-99 ;>99$ & {$[33,35]$} \\
\hline
\end{tabular}

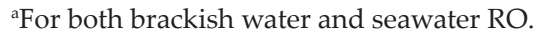

${ }^{\mathrm{b} A c t i v e}$ membrane length is the membrane length producing permeate (between the glue lines).

'The recovery of the LCMTC is lower since a membrane is present only at one side of the feed spacer.

\subsubsection{Relationship between pressure drop and linear flow} velocity

The approach to quantify the hydraulic behaviour in fullscale SWM and spacer-filled flow channels, developed by Schock and Miquel [34], was used to validate the hydrodynamic performance of the LCMTC. The relationship between the pressure drop $\Delta p$ and effective crossflow velocity $v_{\text {eff }}$ in spacer-filled channels is described according to the following equation:

$\Delta p=\frac{\lambda \cdot v_{\mathrm{eff}^{2}} \cdot \rho \cdot L_{\mathrm{Ch}}}{2 \cdot d_{\mathrm{h}, \mathrm{Sp}}}$

where the pressure drop $\Delta p$ is dependent on the friction coefficient $\lambda$, the effective crossflow velocity $v_{\text {eff }}$ the hydraulic diameter of the spacer-filled channel $d_{\mathrm{h}, \mathrm{Sp}}$, the channel length $L_{\mathrm{Ch}}$ and the density of the fluid $\mathrm{Q}$.

The effective velocity $v_{\text {eff }}$ is calculated from the linear flow velocity $v$ and the porosity $\varepsilon$ of the spacer-filled channel [34]:

$$
\begin{gathered}
v_{\text {eff }}=\frac{v}{\varepsilon} \\
\text { Further, } \\
\varepsilon=1-\frac{V_{\mathrm{sp}}}{V_{\mathrm{tot}}}
\end{gathered}
$$

where $V_{\mathrm{Sp}}$ and $V_{\text {tot }}$ are the volume of the spacer and the total channel volume, respectively.

The friction coefficient $\lambda$ was described empirically as:

$\lambda=6.23 \cdot \operatorname{Re}^{-0.3}$

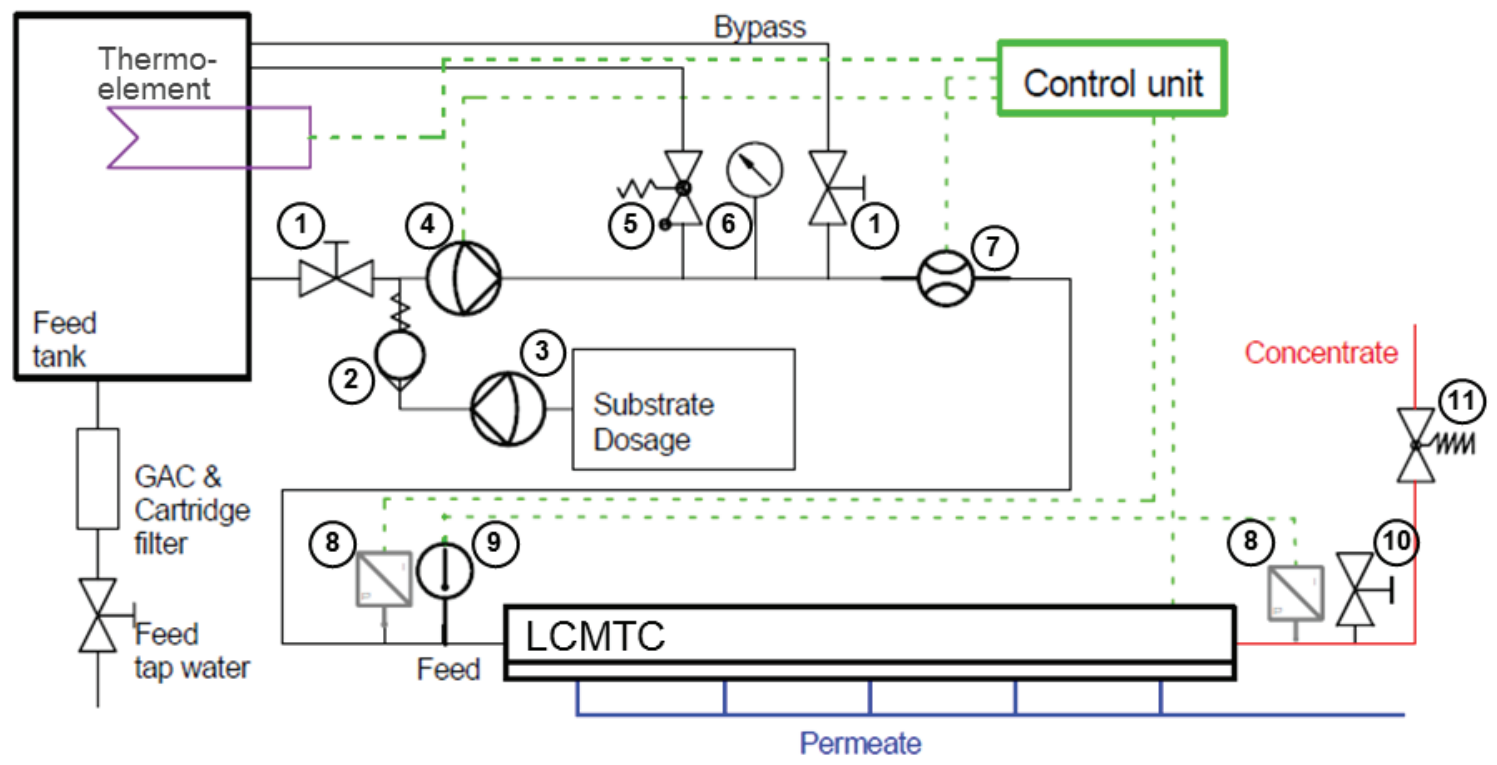

Fig. 3. Flow chart of the developed setup with one Long Channel Membrane Test Cell (LCMTC); 1, safety regulating valve; 2 , nonreturn valve; 3 , dosage pump; 4 , high pressure metering pump; 5 , safety relief valve; 6 , pressure gauge; 7 , flow meter; 8 , pressure sensor; 9, thermometer; 10, sampling valve; and 11, pressure relief valve. 
where

$$
\operatorname{Re}=\frac{\rho \cdot v_{\text {eff }} \cdot d_{h, \text { sp }}}{\eta}
$$

while $\eta$ is the dynamic viscosity.

Thus, for validation of the flow regime in the LCMTC, the pressure drop $(\Delta p)$ in the channel of the LCMTC was determined experimentally and the results were compared with the empirical relationship found by Schock and Miquel [34] for full-scale membrane modules.

For the experiments, two different diamond shaped spacers were used to investigate the impact of the spacer height on the flow profile. Spacer A of $0.787 \mathrm{~mm}$ (31 mil) thickness was purchased from Hydranautics (USA). Spacer A completely filled the feed channel height, in the same way as found in practice (SWM). The other spacer B was $0.711 \mathrm{~mm}$ thick (28 mil, Koch Membrane Systems, USA) and thus of smaller height than the feed channel. The feed pressure was set to 2.5 and 15 bar, respectively. For validation, $\Delta p$ data were collected with an increasing flow velocity followed by a decreasing flow velocity (increasing from $0.09 \mathrm{~m} \mathrm{~s}^{-1}$ and declining from $0.64 \mathrm{~m} \mathrm{~s}^{-1}$ ).

The membrane was taken from a Koch Membrane Systems, USA, FLUID SYSTEMS ${ }^{\circledR}$ TFC $^{\circledR}$-FR 4" ELEMENT module. Before use, the membrane was flushed and compacted for $12 \mathrm{~h}$ with DI water. During the experiment, DI water was used as feed water and the permeation through the membrane was suppressed.

\subsection{Biofouling investigations with one LCMTC}

\subsubsection{Experimental}

In the biofouling study, tap water after passing a $10 \mu \mathrm{m}$ cartridge filter for particle removal and a granular activated carbon filter for chlorine removal (both from Weinert Prozesstechnik GmbH, Germany) was used as the LCMTC feed. To enhance microbial growth, the feed water was supplemented with biodegradable nutrients for bacteria from a stock solution. A pH of 11.5 was maintained in the stock solution to avoid microbial growth. Sodium acetate, sodium dihydrogen phosphate and sodium nitrate (all Merck KGaA, Germany) were dissolved in DI water. The nutrient stock solution was dosed continuously to the feed using a Stepdos dosage pump (KNF, Switzerland) at a flow rate of $28 \mathrm{~mL} \mathrm{~h}^{-1}$, resulting in a feed concentration of $0.5 \mathrm{mg} \mathrm{L}^{-1}$ acetate carbon, $0.1 \mathrm{mg} \mathrm{L}^{-1}$ nitrate nitrogen and $0.05 \mathrm{mg} \mathrm{L}^{-1}$ phosphate phosphorous. The feed water salinity was constant. The test cell system was run continuously for a period of $6 \mathrm{~d}$.

A virgin, low fouling brackish water thin-film composite RO membrane was used for the experiment, obtained from a commercial 4" spiral wound module (ESPA2, Hydranautics, USA). Before the experiments, the membrane system was run with DI water at a pressure of 9 bar for $12 \mathrm{~h}$ to compact the membrane and was stabilized with tap water for $12 \mathrm{~h}$. The inserted feed spacer was a $0.787 \mathrm{~mm}$ (31 mil) diamond shaped spacer from Hydranautics (USA).

The process conditions of the experiments are summarized in Table 2. The temperature, flow rate and system pressure were kept constant. The flux was determined via manual permeate collection (duplicates over $20 \mathrm{~min}$ ). The experiment was stopped when $>10 \%$ permeability decline was achieved, occurring after $6 \mathrm{~d}$.
Table 2

Feed water and LCMTC operating conditions during the biofouling experiment

\begin{tabular}{ll}
\hline Characteristics & Value \\
\hline Temperature, ${ }^{\circ} \mathrm{C}$ & 25 \\
Feed DOC, mg L ${ }^{-1}$ & 0.3 \\
Feed conductivity, $\mu \mathrm{S} \mathrm{cm}^{-1}$ & $\sim 260$ \\
Initial permeate flux, $\mathrm{L} \mathrm{m}^{-2} \mathrm{~h}^{-1}$ & 24 \\
Feed pressure, bar & 4.8 \\
Crossflow velocity (channel entry), $\mathrm{m} \mathrm{s}^{-1}$ & 0.16 \\
Feed inflow, $\mathrm{L} \mathrm{h}^{-1}$ & 15.5 \\
Initial recovery, \% & 5.6 \\
Nutrient dosage (carbon), $\mathrm{mg} \mathrm{C} \mathrm{L}^{-1}$ & 0.5 \\
Spacer thickness, mm & 0.787 \\
Effective channel length, $\mathrm{m}$ & 0.91 \\
\hline
\end{tabular}

The FCP was calculated as follows:

$\Delta p=p_{\text {in }}-p_{\text {out }}$

The permeability $P_{\text {Seg }}$ is the flux of a segment $J_{\text {Seg }}$ divided by the corresponding average pressure $\overline{p_{\text {seg }}}$ :

$P_{\text {Seg }}=\frac{J_{\text {Seg }}}{\overline{p_{\text {Seg }}}}$

It was assumed that the pressure drop over the length of the membrane module was linear.

The salt in each of the five segments, $S_{\mathrm{Seg}^{\prime}}$ was obtained as follows:

$S_{\text {Seg }}=\frac{C_{P, \text { Seg }}}{\overline{C_{F, \text { Seg }}}} \cdot 100 \%$

Here, $C_{P, \text { Seg }}$ is the permeate conductivity of each of the five segments over the LCMTC length and $\overline{C_{F, \text { seg }}}$ is the average feed concentration for each segment, assuming a linear increase of the salt concentration over the length of the feed channel, due to permeate production.

\subsubsection{Analysis of the fouling layer}

When the experiment was completed, the fouling layer was removed from both the membrane and the feed spacer, separately for each of the five permeate producing segments. The membrane sheet of each of the five segments over the LCMTC length together with the corresponding spacer was placed in a tube with $50 \mathrm{~mL}$ DI water to measure the specific amount of foulant per membrane surface area and spacer. Shortly after sampling, the membrane and spacer were treated with ultrasound for extraction and dispersion of the foulant. The treatment procedure was performed with an ultrasonic water bath (output $45 \mathrm{kHz}, 130 \mathrm{~W}$, VWR Ultrasonic Cleaner, Germany) for $6 \times 2$ min and in between mixing with a vortex shaker (VV3, VWR, Germany) for $15 \mathrm{~s}$. The removal of biomass from the membrane and spacer was applied according to Bucs et al. [37], Magic-Knezev and van der Kooij 
[38] and Vrouwenvelder et al. [39]. The suspension was then analyzed with a liquid chromatography-organic carbon detection (LC-OCD) system, Model 8, DOC Labor Huber (Karlsruhe, Germany) for determination and quantification of the dissolved organic carbon (DOC) fractions. The analysis is based on size exclusion chromatography performed with a weak cation exchange chromatographic column (TSK HW 50S, Toso, Japan). The amounts of DOC of the extracted foulants are determined by organic carbon detection. The device contains a $0.45-\mu \mathrm{m}$ filter prior to the size exclusion column. The ChromCALC software provided by the manufacturer of the instrument was used for analysis and interpretation of the chromatograms.

In addition to organic material, also active biomass (adenosine triphosphate [ATP]) was determined. Samples were prepared according to the technical bulletin of the BacTiterGlo ${ }^{\mathrm{TM}}$ reagent and measured with the multi-functional reader INFINITE 200 Pro (Tecan, Germany) at $570 \mathrm{~nm}$ wavelength. Calibration was done using an ATP stock solution (Sigma-Aldrich, Germany).

\subsection{Overview of the studies performed}

An overview of all studies with their goals and methods is given in Table 3 .

\section{Results}

In this study, the LCMTC was tested (i) on representativeness for spiral-wound NF/RO membrane elements (section 3.1) and (ii) on the development of membrane performance indicators during biofouling. The FCP, permeability and salt passage were monitored over five segments over the test cell and compared with the accumulated biomass amount and composition on these five locations (section 3.2, Table 2).

\subsection{Validation studies}

\subsubsection{Flow field distribution}

The flow field distribution in the flow channel of the LCMTC was assessed by pulse injection of a red coloured solution (containing the dye Rhodamine B) into the feed water of the test cell. The flow field was homogeneously distributed over the width of the cell (Fig. 4). The same flow behavior has been found in SWMs [40] and smaller sized test cells [23].

\subsubsection{Hydraulic characterization for the same spacer thickness and flow channel height}

For the LCMTC, the relation between the crossflow velocity and FCP was determined experimentally and compared with the relationship calculated according to Shock and Miquel [34]. A $31 \mathrm{mil}(0.787 \mathrm{~mm})$ thick feed spacer was placed in a 31 mil height flow channel.

The measured relation between the crossflow velocity and pressure drop for the test cell matched the calculated relation (Fig. 5(A)). The measured relation between the crossflow velocity and FCP was not affected by the feed water pressure (Fig. 5(A)), illustrating the high rigidity of the test cell geometry.

Testing of the membrane test cell (LCMTC) showed it to be representative of the flow field and the hydraulic behavior of SWMs used in practice.

\subsubsection{Hydraulic characterization for a larger flow channel height than spacer thickness}

The impact of the feed spacer thickness in a fixed flow channel height on the relation between the crossflow velocity and pressure drop was assessed in a $31 \mathrm{mil}(0.787 \mathrm{~mm})$ high flow channel, containing (i) a 31 mil thick feed spacer and (ii) a $28 \mathrm{mil}(0.711 \mathrm{~mm})$ thick feed spacer.

As shown in section 3.1.2, the LCMTC with a feed spacer matching the flow channel height (both $31 \mathrm{mil}$ ) showed a good agreement of the measured and calculated relation between the crossflow velocity and pressure drop (Fig. 5(A)). The thinner 28 mil feed spacer in the same flow channel height showed a difference between the measured and calculated relation between crossflow velocity and pressure drop (Fig. 5(B)), illustrating that the feed spacer thickness should match the flow channel height to simulate an SWM. In other words, the same hydraulic behaviour as

Table 3

Schematic overview of studies performed

\begin{tabular}{|c|c|c|c|c|}
\hline Study/goal & Conditions/details & Methods & Feed spacer thickness & Section \\
\hline Validation flow field distribution & Flow channel with spacer & $\begin{array}{l}\text { Flow field visualization } \\
\text { with tracer }\end{array}$ & $31 \mathrm{mil}$ & 3.2 .1 \\
\hline \multirow[t]{2}{*}{ Validation hydraulic behaviour } & \multirow{2}{*}{$\begin{array}{l}\text { LCMTC comparison } \\
\text { with SWM, feed channel } \\
\text { pressure drop, flow } \\
\text { velocity }\end{array}$} & Appropriate spacer & $31 \mathrm{mil}$ & 3.2 .1 \\
\hline & & Inappropriate spacer & $28 \mathrm{mil}$ & 3.2 .1 \\
\hline \multirow[t]{3}{*}{ Biofouling investigation } & $\begin{array}{l}\mathrm{FCP} \text {, permeability, salt } \\
\text { passage }\end{array}$ & Membrane performance & $31 \mathrm{mil}$ & 3.2 .2 \\
\hline & $\begin{array}{l}\mathrm{FCP} \text {, permeability, salt } \\
\text { passage }\end{array}$ & $\begin{array}{l}\text { Membrane performance } \\
\text { over length }\end{array}$ & $31 \mathrm{mil}$ & 3.2 .2 \\
\hline & Fouling layer composition & $\begin{array}{l}\text { Extraction of foulants } \\
\text { analysis }\end{array}$ & $31 \mathrm{mil}$ & 3.2 .2 \\
\hline
\end{tabular}



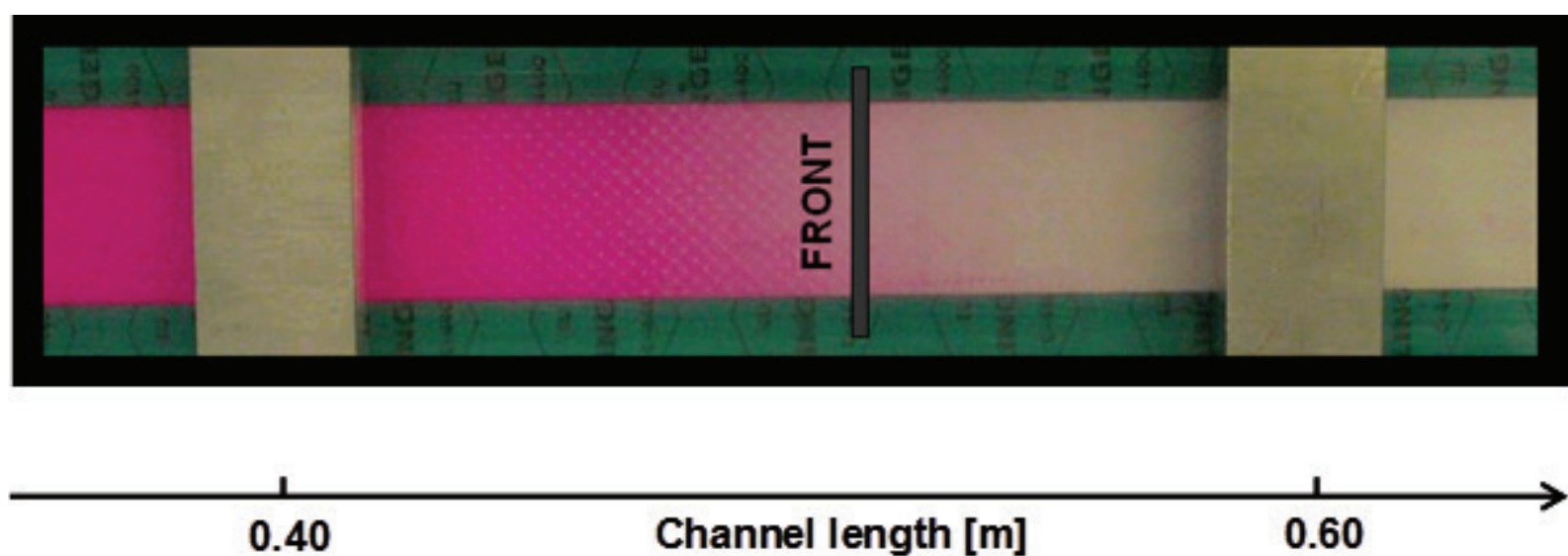

Channel length [m]

0.60

Fig. 4. Flow profile in the LCMTC, visualized by injecting a pulse of a red coloured dye (Rhodamine B) to the feed water at length $0.40-0.60 \mathrm{~m}$ of the flow channel, containing a 31 mil thick feed spacer. Side bars in the picture originate from the metal frame on the test cell top lid.
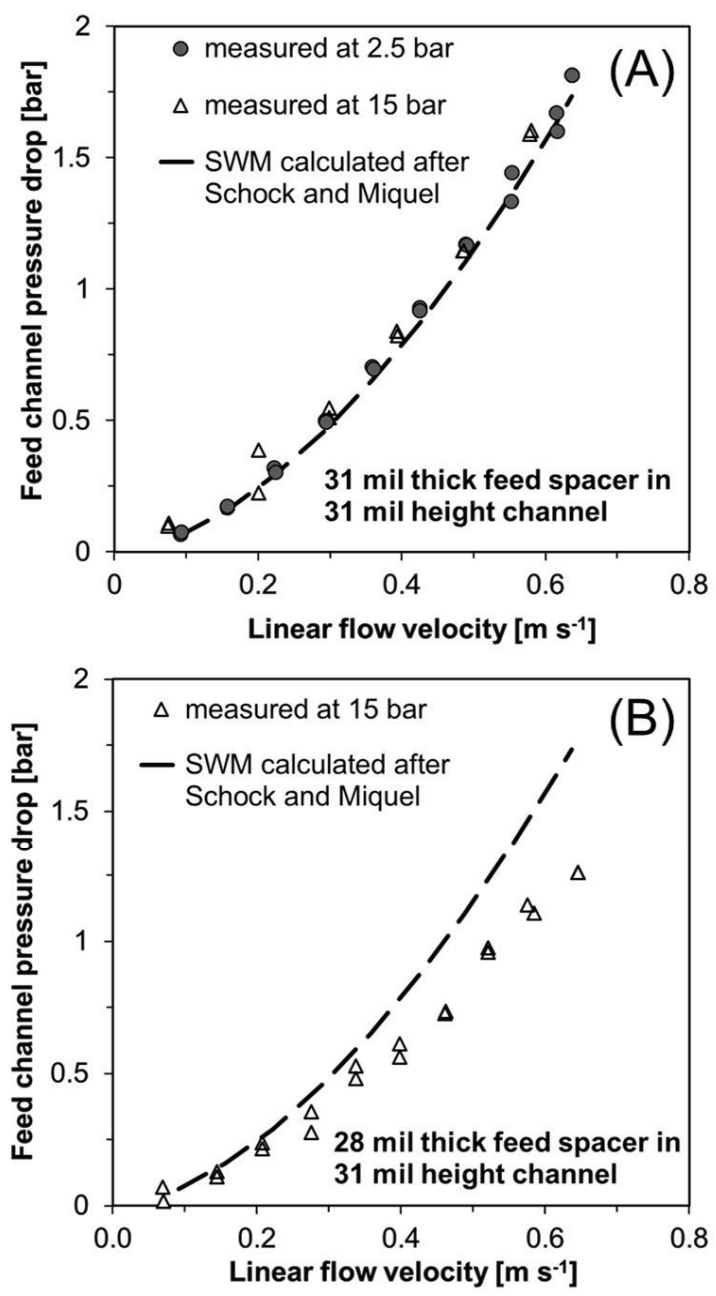

Fig. 5. Feed channel pressure drop dependency of linear flow velocity for the LCMTC (A) using a feed spacer of the same height as the feed channel and (B) using a feed spacer smaller than the channel height. The dashed lines represent calculated data of SWM by the relationship given by Schock and Miquel [34]. in SWMs is achieved in a test cell only when the feed spacer fits the flow channel height.

For a representative flow field and hydraulic behaviour of the LCMTC matching spacer thickness and flow channel height should be applied.

\subsection{Biofouling studies}

\subsubsection{Development of membrane performance over the total cell length}

The test cell, containing a 31 mil feed spacer in a $31 \mathrm{mil}$ height flow channel and a membrane was (i) operated at constant feed flow and (ii) fed with tap water supplemented with a biodegradable compound (acetate) to enhance the biofouling rate (Table 2). Performance indicators FCP, permeability and salt passage were monitored over time.

With time, the permeability declined (Fig. 6(A)), FCP increased (Fig. 6(B)) and salt passage increased (Fig. 6(C)). During the six-day study, the pressure drop increased from 0.2 to 2.0 bar ( $900 \%$ increase). At the end of the six-day study, the permeability was decreased by $13 \%$, and salt passage was increased by $50 \%$. Biofouling affected all membrane performance indicators.

The test cell is suitable to simultaneously monitor all membrane performance indicators.

\subsubsection{Development of membrane performance over five segments of the test cell length}

The development with time of permeability and salt passage over five segments of the test cell was monitored during the biofouling study. Each of the five segments had the same length (Fig. 2). The permeate producing segments were located at $0-18,18-36,36-54,54-72$ and $72-90 \mathrm{~cm}$ of the test cell feed side. The feed water salinity was constant.

The permeability decreased gradually with time (Fig. 7). The strongest and fastest permeability decline occurred at the lead segment $(0-18 \mathrm{~cm})$ directly after the test cell inlet. With increasing distance to the test cell feed side, the permeability decline was reduced. After the six-day study, the permeability 

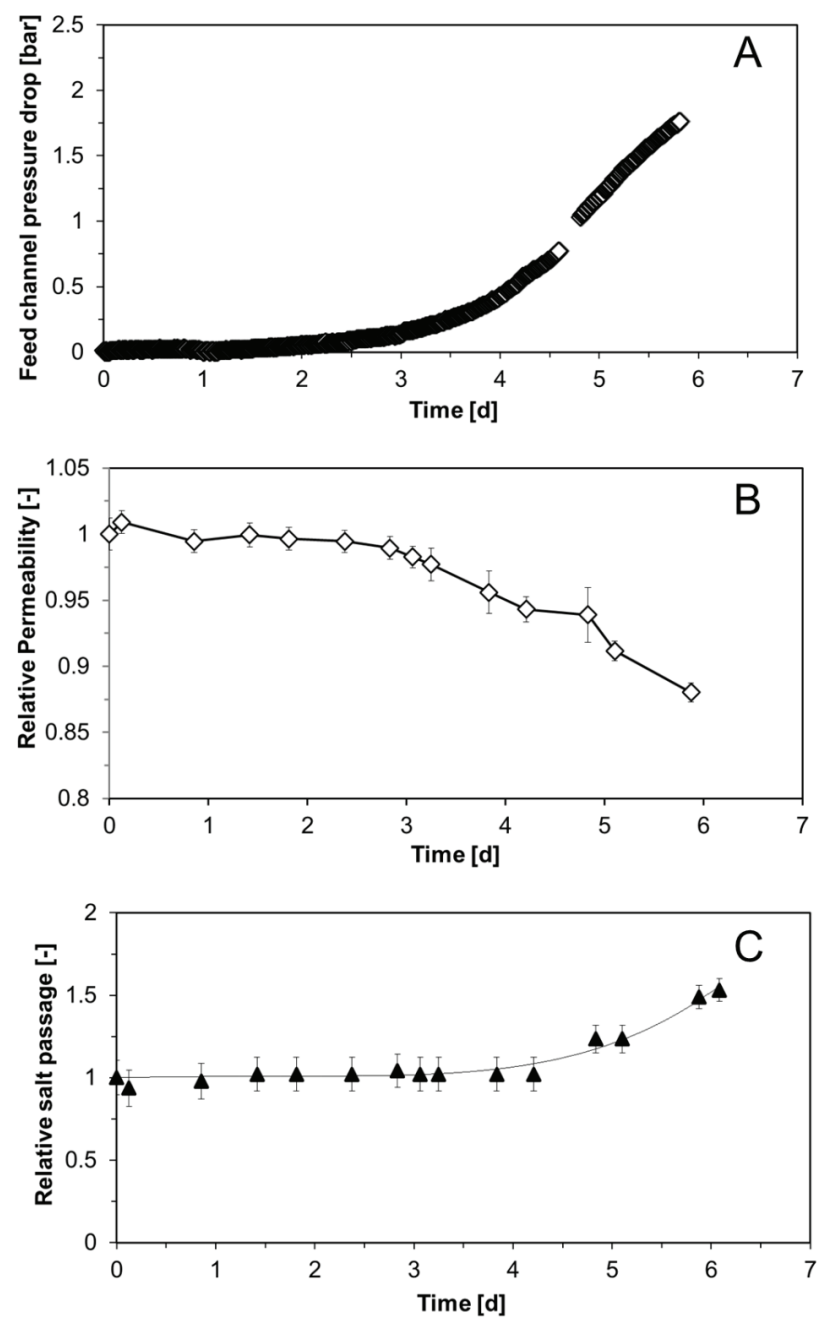

Fig. 6. Membrane performance with time in the test cell: (A) feed channel pressure drop increase, (B) permeability decline and (C) salt passage increase. The cell was fed with feed water supplemented with $0.5 \mathrm{mg} \mathrm{C} \mathrm{L}^{-1}$ to accelerate biofouling development. Error bars refer to standard deviation (permeability, $n=5$ ) and method standard deviation (salt passage).

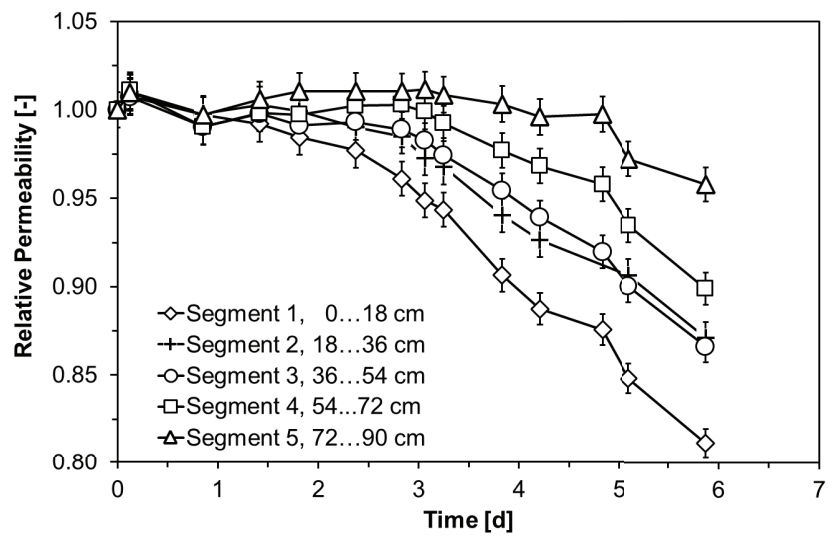

Fig. 7. Relative permeability decline over the test cell length in time over the test cell length (five segments) during biofouling development. Error bars indicate method standard deviation. decline of the first segment $(0-18 \mathrm{~cm})$ was $20 \%$ and of the last segment $(72-90 \mathrm{~cm}$ ) was 3\%. The resistance of the fouling layer was calculated from the permeability data (supplementary material, Fig. S9). The resistance of the fouling layer was highest at the test cell inlet side and decreased with increasing distance to the test cell feed side.

Salt passage was constant during the first $4 \mathrm{~d}$ (Fig. 8). From day four, salt passage at all segments over the test cell length increased simultaneously to the same extent. At the end of the $6 \mathrm{~d}$ biofouling study, salt passage had increased by more than $50 \%$. Salt passage is impacted by biofilm enhanced osmotic pressure as well as the reduction in flux (dilution effect), both leading to an increasing salt concentration in the permeate. The strong relative increase in salt passage is caused by the very high initial salt rejection.

Biofilm formation affected both permeability and salt passage negatively. Over the test cell length with time (i) the highest permeability decline occurred at the inlet side, while (ii) the salt passage increased simultaneously to the same extent at all sections of the test cell.

\subsubsection{Characterization of accumulated biomass over five segments of the test cell length}

At the end of the six-day study the test cell was opened to sample the feed spacer and membrane for accumulated biomass analysis, by measuring ATP, DOC and DOC fractions (LC-OCD).

The concentrations of active biomass (ATP, Fig. 9(A)) and DOC (Fig. 9(B)) were highest at the test cell inlet side (first $18 \mathrm{~cm}$ ) and declined over the length of the test cell. Over the total test cell length the ATP concentration decreased from

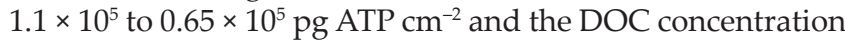
decreased from 20 to $13 \mu \mathrm{g}$ DOC $\mathrm{cm}^{-2}$.

The extracted organic material was analyzed by LC-OCD and classified according to Huber [41]. The accumulated organic material was mainly composed of biopolymers $(\sim 50 \%)$ and the smallest amount was attributed to low molecular weight acids ( 1\%, Fig. 9(C)).

The highest biomass concentrations were found on the membrane and feed spacer present at the inlet side

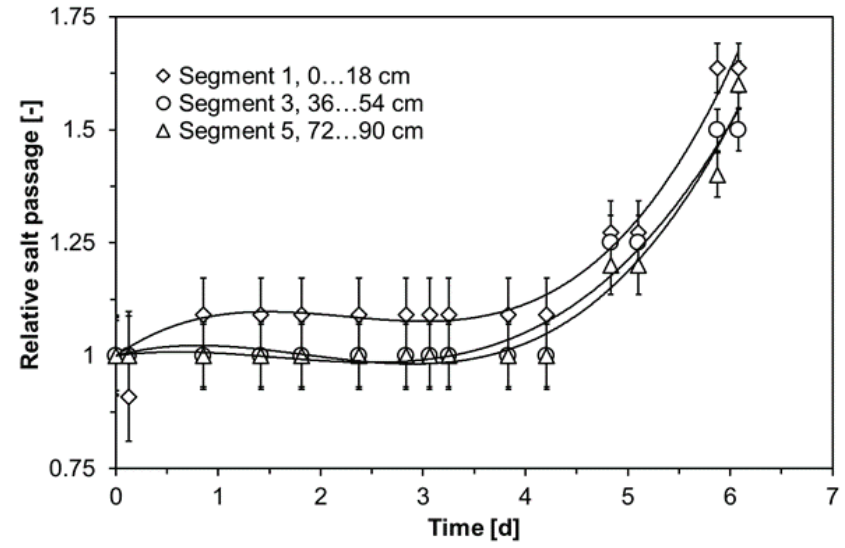

Fig. 8. Relative salt passage in time over the test cell length (segments 1, 3 and 5) during biofouling development. Error bars indicate method standard deviation. 

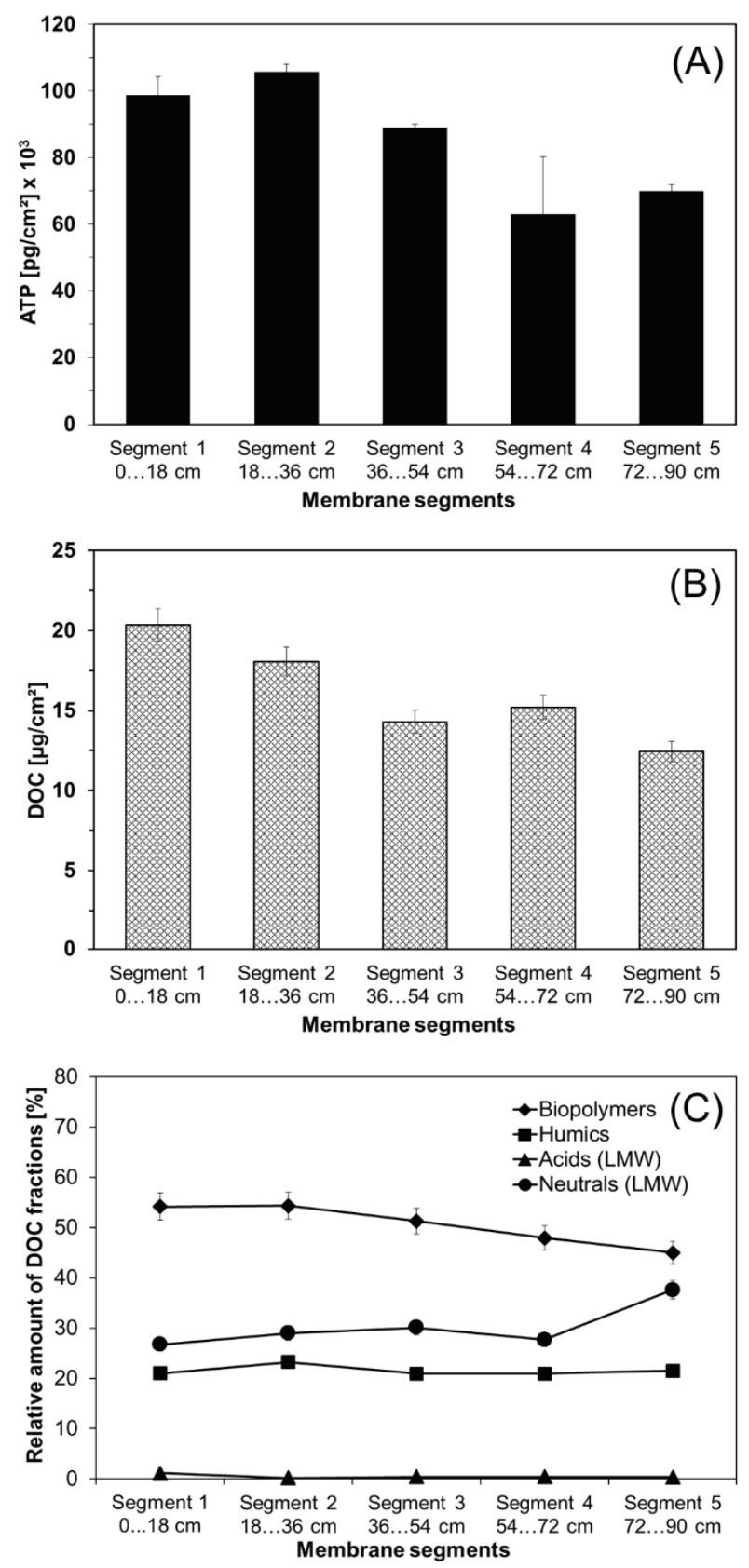

Fig. 9. Foulants on the membrane surface in different segments after $6 \mathrm{~d}$ biofouling study. (A) Biomass, measured as ATP per membrane surface area. (B) Organic carbon, measured as DOC per membrane surface area. (C) Variation of the relative contribution of different DOC fractions to the DOC surface concentration. Error bars indicate method standard deviation.

(first $18 \mathrm{~cm}$ ) of the test cell, characteristic of biofilm accumulation in spiral-wound membrane systems.

\section{Discussion}

\subsection{Representative test cells for practice needed}

Many membrane biofouling test cell studies have been described, from which the conditions (e.g., hydrodynamics, spatial dimension of the flow channel, use of membrane and spacer) are not representative for conditions of pilot and full-scale membrane installations. However, a biofouling control approach effective under non-representative laboratory conditions is most probably not predictive for full-scale applications [26].

Many biofouling test cells/monitors have been presented as suitable tools for biofouling control studies. In general, no data on test cell validation is included, while a critical evaluation of the representativeness of the test cell study results for practice (i.e., hydrodynamic validation) hardly exists. For a comprehensive understanding of biofouling control, it is essential to address and report test cell validation [26].

A series of validation tests with the LCMTC showed the representativeness of the spatial flow channel dimensions and hydraulic behaviour for membranes applied in practice, similar to tests performed with the membrane fouling simulator [23] and the transparent membrane biofouling monitor [42].

The LCMTC study with two different thicknesses of feed spacer ( 28 and $31 \mathrm{mil}$ ) in the same flow channel height (31 mil) demonstrated the necessity to use a feed spacer fitting the flow channel (Figs. 5(A) and (B)). A feed spacer matching the flow channel height showed a good agreement of the measured and calculated relation between the crossflow velocity and pressure drop. However, when a thinner feed spacer was used in the same flow channel height, differences were found between the measured and calculated relation between the crossflow velocity and pressure drop. When the feed spacer thickness is smaller than the feed channel height (i) part of the water flow bypasses the spacer, (ii) causing a disturbed flow field leading to a reduced pressure drop over the spacer channel and thus (iii) unrepresentative deposition of particles, bacteria, colloids and large molecules like extracellular polymeric substances will occur in the spacer channel. Therefore, both the development of the fouling layer with time and the membrane performance will be affected. The feed spacer creates a characteristic hydrodynamic environment leading to specific flow conditions and mass transport. Therefore, any fouling formation is strongly impacted by the presence of a feed spacer. Operating the flow cell under non-representative conditions for practice (such as without a feed spacer or with a feed spacer not fitting the flow channel height, too low crossflow velocity and too high permeate flux) could lead to biofouling control strategies that are not effective in practice. Here, especially the combination of substrate availability and substrate transport in a channel filled with a feed spacer resulted in a FCP due to vertical hydraulic resistance. Our study underlines (i) the important role of the feed spacer in test cells to study fouling formation and control strategies and (ii) the need to report validation studies of test cells.

\subsection{Evaluation of the test cell}

The developed LCMTC is representative of spiral-wound membrane modules (SWMs) with regard to the flow field distribution (Fig. 4), flow channel height, hydraulic behaviour (Fig. 5(A)), and membrane and feed spacer length (Table 1). The spacer thickness should match the flow channel height (Figs. 5(A) and (B)). Over the test cell, all the SWM 
performance indicators - FCP, permeate flux and salt passage - can be monitored simultaneously (Fig. 6). Both permeate flux and salt passage can be monitored for five segments over the test cell length (Figs. 7 and 8 ) and compared with the amount and composition of accumulated biomass in these five segments (Fig. 9), illustrating the unique features of the test cell. The cell can be operated with varying feed spacer thickness matching the flow channel height, at linear flow velocities and permeate fluxes, at various feed pressures. The test cell can be opened non-destructively to sample the feed spacer and membrane sheet for analysis of accumulated foulant. The flow channel width $(0.040 \mathrm{~m})$ of the LCMTC flow channel enables a much lower use of feed water and chemicals compared with an SWM installation (pilot).

The biofouling study showed a rapid response of all membrane performance indicators in time. With increasing distance to the test cell feed side, the permeability decline and the amount of biomass was reduced. The first $20 \mathrm{~cm}$ of the test cell showed the strongest permeate flux decline and the most accumulated biomass. Various studies on NF and RO SWMs [20,39] have shown a declining gradient of accumulated biomass with increasing distance to the lead membrane module feed side, in agreement with our findings with the LCMTC. The uptake of biodegradable substrate by bacterial cells in the lead membrane elements leads to a reduced availability of substrate in the tail parts of the device [20,39].

At the end of the biofouling study, the amount of accumulated biomass over the membrane length was determined. The ATP concentration on the membrane and feed

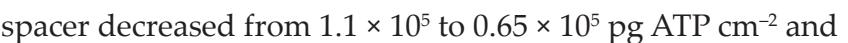
the DOC concentration from 20 to $13 \mu \mathrm{g}$ DOC $\mathrm{cm}^{-2}$. Similar concentration ranges for ATP and DOC were found during studies on membrane modules from full-scale installations and test cells suffering from reduced membrane performance caused by biofouling. Miller et al. [43] found ATP concentrations from about $0.2 \times 10^{5}$ up to $2.0 \times 10^{5} \mathrm{pg}$ ATP $\mathrm{cm}^{-2}$ in a biofouling experiment with membranes and spacers precoated with polydopamine. Dreszer et al. [42] found 70-90 $\mu \mathrm{g}$ TOC $\mathrm{cm}^{-2}$ in lab-scale biofouling studies without feed spacer on the hydraulic biofilm resistance. The amount and distribution of fouling over the LCMTC is in agreement with data from full-scale membrane modules and lab-scale test cell biofouling studies, as reported earlier [39,42,43], underlining the suitability of the LCMTC for membrane fouling research. Hence, the present study with the LCMTC mirrors fouling formation as found in SWMs in practice. In future studies, a more detailed investigation with sterile control runs should be conducted enabling to distinguish biotic and abiotic effects in fouling formation, revealing more insights on fouling characterization. Furthermore, it is proposed to determine additional biomass parameters such as protein, carbohydrates and total bacteria concentrations.

There is a suite of test cells/monitors available for membrane and feed spacer (bio)fouling studies [22,23,26,44,45]. A unique feature of the LCMTC is that the permeate flux and salt passage can be monitored for five consecutive segments over the test cell length and compared with the amount of the accumulated biofilm and composition in these five segments. Information on the development over the membrane module length of membrane performance and fouling accumulation will (i) increase the understanding of the impact of biofouling on membrane performance and (ii) contribute to the development of knowledge-based strategies for biofouling control.

\subsection{Potential fields of LCMTC use}

The accumulation of biomass may impact membrane performance in several ways. Biofouling of the membrane causes an additional hydraulic resistance decreasing the permeability and increasing the salt passage $[26,46]$. Biofouling of the feed spacer may lead to flow channeling, causing an increase of FCP, and the flow channeling may lead to dead zones in the membrane module where permeate production is reduced and salt passage is increased. The developed LCMTC is suitable to determine the development of membrane performance indicators and fouling over the full length of a membrane element. A better insight of the impact of biofouling on membrane performance, in which order and to which degree the membrane performance indicators are influenced, is provided. Such insights enable a better monitoring strategy for membrane fouling and the development of membrane systems that are less susceptible to (bio)fouling.

The operation of LCMTC cells in series enables the simulation of a pilot/full-scale plant at a smaller scale and foot print and a lower water and chemical use (e.g., antiscalant). For example, six cells can be tested in series to simulate a pressure vessel containing six membrane elements. The water used by six cells in series at a feed flow velocity of $0.2 \mathrm{~m} \mathrm{~s}^{-1}$ would be about $19 \mathrm{~L} \mathrm{~h}^{-1}$, which is much less than, for example, a single element test rig with the same linear flow velocity containing a 4-inch-diameter spiral-wound membrane element $\left(1,960 \mathrm{~L} \mathrm{~h}^{-1}\right)$ or a 8-inch diameter membrane element $\left(9,800 \mathrm{~L} \mathrm{~h}^{-1}\right)$. Besides the water use also the use of chemicals (e.g., antiscalant, biocide) is greatly reduced.

Parallel operation of LCMTC cells enables comparing fouling control strategies. The impact of operational aspects such as crossflow velocity and permeate flux, modified membranes and the geometry of feed spacers can be determined. Fouled cells with the same history of parallel operation on site can be cleaned with various chemicals and cleaning regimes to select the most effective strategy with minimal cost and environmental impact. Preventive and curative (bio)fouling control strategies can be studied using cells in parallel operation. Pretreatment strategies and their impact on fouling reduction can be compared in research with the device, even revealing details on long-term effects in full-scale operation. Deposited foulants can be characterized with various analytical methods and connected to the influent characteristics, as well as membrane performance.

\section{Conclusions}

Results presented in this paper led to the following conclusions:

- The LCMTC is representative for spiral-wound membrane modules (SWMs). The LCMTC has the same (i) flow field distribution, (ii) flow channel height, (iii) hydraulic behaviour and (iv) membrane and feed spacer length as industrial SWMs. 
- The LCMTC is suitable to simultaneously monitor all SWM performance indicators: Feed channel pressure drop, permeability and salt passage.

- The LCMTC enables monitoring of the permeate flux and salt passage over five segments of the test cell, which can be compared with the amount and composition of accumulated biomass on these five locations.

- The LCMTC can be operated (i) with varying feed spacer thicknesses in a matching the feed channel, (ii) at linear flow velocities and permeate fluxes as applied in practice, (iii) at various feed pressures and (iv) with lower water usage and smaller foot print compared with SWM installations (pilot).

- The LCMTC can be opened non-destructively to sample the feed spacer and membrane sheet for analysis of accumulated fouling.

The LCMTC is suitable to study, under conditions that are representative for membrane elements used in practice, the impact of biofilm development and biofouling control strategies on all membrane module performance indicators.

\section{Acknowledgements}

The authors thank the German Federal Ministry of Education and Research (BMBF) for the financial support of the project "Fouling minimized reclamation of secondary effluents with Reverse Osmosis" (ReSeRO) under grant no. 02WA1076. Further, several people have given time and efforts on discussion of the introduced topic and are thus thanked Mr. A. Lerch (Chair of Water Supply Engineering, TU Dresden, Germany) for stimulating suggestions during the construction of the LCMTC, Mrs. J. Brückner, Mr. G. Orzechowski and Mr. D. Diersche (Chair of Water Supply Engineering, TU Dresden, Germany) for their help regarding analysis and support on the setup of the test rig, respectively, Mr. D. Kreutzmann and Mr. M. Meinel for discussions on material strength and tensions, Mr. J. Friedrich (Institute of Lightweight Engineering and Polymer Technology, TU Dresden) for the supply of the PMMA model calculation on material strength and Mr. S. Bucs (KAUST) for his help with the Rhodamine B experiment.

\section{Abbreviations and symbols}

$\begin{array}{lll}\text { ATP } & - & \text { Adenosine triphosphate } \\ \text { CP } & - & \text { Concentration polarization } \\ \text { DI } & - & \text { Deionized } \\ \text { DOC } & - & \text { Dissolved organic carbon } \\ \text { FCP } & - & \text { Feed channel pressure drop } \\ \text { LCMTC } & - & \text { Long-channel membrane test cell } \\ \text { LC-OCD } & - & \text { Liquid chromatography-organic carbon } \\ \text { detection } & \\ \text { NF } & - & \text { Nanofiltration } \\ \text { PMMA } & - & \text { Polymethyl methacrylate } \\ \text { RO } & - & \text { Reverse osmosis } \\ \text { SWM } & - & \text { Spiral-wound membrane module } \\ \overline{p_{\text {Seg }}} & - & \text { Average pressure over a segment, bar } \\ C_{F, \text { Seg }} & - & \text { Average feed conductivity over a segment, } \\ & & \end{array}$

$\begin{array}{lll}C_{P, \text { Seg }} & - & \text { Permeate conductivity for a segment, } \mu \mathrm{Cm}^{-2} \\ d_{h, \mathrm{Sp}} & - & \text { Hydraulic diameter of the spacer, } \mathrm{m} \\ J_{\mathrm{Seg}} & - & \text { Flux of a segment, } \mathrm{L} \mathrm{m}^{-2} \mathrm{~h}^{-1} \\ L_{\mathrm{Ch}} & - & \text { Channel length, } \mathrm{m} \\ p_{\text {in }} & - & \text { Inlet pressure, bar } \\ p_{\text {out }} & - & \text { Outlet pressure, bar } \\ P_{\mathrm{Seg}} & - & \text { Permeability of a segment, } \mathrm{L} \mathrm{m}^{-2} \mathrm{~h}^{-1} \mathrm{bar}^{-1} \\ \mathrm{Re} & - & \text { Reynolds number } \\ S_{\mathrm{Seg}} & - & \text { Salt passage of a segment, } \% \\ v & - & \text { Linear crossflow velocity, } \mathrm{m} \mathrm{s}^{-1} \\ v_{\text {eff }} & - & \text { Effective flow velocity, } \mathrm{m} \mathrm{s}^{-1} \\ V_{\mathrm{Sp}} & - & \text { Volume of the spacer, } \mathrm{m}^{3} \\ V_{\text {tot }} & - & \text { Total channel volume, } \mathrm{m}^{3} \\ \Delta p & - & \text { Pressure drop, bar } \\ \varepsilon & - & \text { Porosity } \\ \eta & - & \text { Dynamic viscosity, } \mathrm{kg} \mathrm{m}^{-1} \mathrm{~s}^{-2} \\ \lambda & - & \text { Friction coefficient }\end{array}$

\section{References}

[1] W.L. Ang, D. Nordin, A.W. Mohammad, A. Benamor, N. Hilal, Effect of membrane performance including fouling on cost optimization in brackish water desalination process, Chem. Eng. Res. Des., 117 (2017) 401-413.

[2] J.S. Vrouwenvelder, M.C.M. Van Loosdrecht, J.C. Kruithof, A novel scenario for biofouling control of spiral wound membrane systems, Water Res., 45 (2011) 3890-3898.

[3] M. Herzberg, M. Elimelech, Biofouling of reverse osmosis membranes: role of biofilm-enhanced osmotic pressure, J. Membr. Sci., 295 (2007) 11-20.

[4] M. Herzberg, S. Kang, M. Elimelech, Role of extracellular polymeric substances (EPS) in biofouling of reverse osmosis membranes, Environ. Sci. Technol., 43 (2009) 4393-4398.

[5] H. Mo, K.G. Tay, H.Y. Ng, Fouling of reverse osmosis membrane by protein (BSA): effects of $\mathrm{pH}$, calcium, magnesium, ionic strength and temperature, J. Membr. Sci., 315 (2008) 28-35.

[6] C. Picioreanu, J.S. Vrouwenvelder, M.C.M. van Loosdrecht, Three-dimensional modeling of biofouling and fluid dynamics in feed spacer channels of membrane devices, J. Membr. Sci., 345 (2009) 340-354.

[7] A.I. Schaefer, A.G. Fane, T.D. Waite, Nanofiltration: Principles and Applications, 1st ed., Elsevier, Oxford, UK; New York, NY, 2005.

[8] T.H. Chong, F.S. Wong, A.G. Fane, The effect of imposed flux on biofouling in reverse osmosis: Role of concentration polarisation and biofilm enhanced osmotic pressure phenomena, J. Membr. Sci., 325 (2008) 840-850.

[9] T.H. Chong, F.S. Wong, A.G. Fane, Implications of critical flux and cake enhanced osmotic pressure (CEOP) on colloidal fouling in reverse osmosis: experimental observations, J. Membr. Sci., 314 (2008) 101-111.

[10] A.I. Radu, J.S. Vrouwenvelder, M.C.M. van Loosdrecht, C. Picioreanu, Modeling the effect of biofilm formation on reverse osmosis performance: flux, feed channel pressure drop and solute passage, J. Membr. Sci., 365 (2010) 1-15.

[11] G.A. Fimbres-Weihs, D.E. Wiley, Review of 3D CFD modeling of flow and mass transfer in narrow spacer-filled channels in membrane modules, Chem. Eng. Process., 49 (2010) 759-781.

[12] H. Mo, H.Y. Ng, An experimental study on the effect of spacer on concentration polarization in a long channel reverse osmosis membrane cell, Water Sci. Technol., 61 (2010) 2035-2041.

[13] P.A. Araujo, J.C. Kruithof, M.C.M. Van Loosdrecht, J.S. Vrouwenvelder, The potential of standard and modified feed spacers for biofouling control, J. Membr. Sci., 403 (2012) $58-70$.

[14] B.R. Gu, C.S. Adjiman, X.Y. Xu, The effect of feed spacer geometry on membrane performance and concentration polarisation based on 3D CFD simulations, J. Membr. Sci., 527 (2017) 78-91. 
[15] S.S. Sablani, M.F.A. Goosen, R. Al-Belushi, V. Gerardos, Influence of spacer thickness on permeate flux in spiral-wound seawater reverse osmosis systems, Desalination, 146 (2002) 225-230.

[16] C.C. Zimmerer, V. Kottke, Effects of spacer geometry on pressure drop, mass transfer, mixing behavior, and residence time distribution, Desalination, 104 (1996) 129-134.

[17] M.F. Hamoda, N.F. Attia, I.A. Al-Ghusain, Performance evaluation of a wastewater reclamation plant using ultrafiltration and reverse osmosis, Desal. Wat. Treat., 54 (2015) 2928-2938.

[18] C.P. Koutsou, A.J. Karabelas, M. Kostoglou, Membrane desalination under constant water recovery - the effect of module design parameters on system performance, Sep. Purif. Technol., 147 (2015) 90-113.

[19] L.F. Song, K.G. Tay, Performance prediction of a long crossflow reverse osmosis membrane channel, J. Membr. Sci., 281 (2006) 163-169.

[20] R.P. Carnahan, L. Bolin, W. Suratt, Biofouling of Pvd-1 reverseosmosis elements in the water-treatment plant of the City of Dunedin, Florida, Desalination, 102 (1995) 235-244.

[21] F. Tang, H.-Y. Hu, L.-J. Sun, Y.-X. Sun, N. Shi, J.C. Crittenden, Fouling characteristics of reverse osmosis membranes at different positions of a full-scale plant for municipal wastewater reclamation, Water Res., 90 (2016) 329-336.

[22] S.R. Suwarno, X. Chen, T.H. Chong, V.L. Puspitasari, D. McDougald, Y. Cohen, S.A. Rice, A.G. Fane, The impact of flux and spacers on biofilm development on reverse osmosis membranes, J. Membr. Sci., 405 (2012) 219-232.

[23] J.S. Vrouwenvelder, J.A.M. van Paassen, L.P. Wessels, A.F. van Dama, S.M. Bakker, The membrane fouling simulator: a practical tool for fouling prediction and control, J. Membr. Sci., 281 (2006) 316-324.

[24] X.F. Huang, G.R. Guillen, E.M.V. Hoek, A new high-pressure optical membrane module for direct observation of seawater RO membrane fouling and cleaning, J. Membr. Sci., 364 (2010) 149-156.

[25] S.T.V. Sim, W.B. Krantz, T.H. Chong, A.G. Fane, Online monitor for the reverse osmosis spiral wound module-development of the canary cell, Desalination, 368 (2015) 48-59.

[26] C. Dreszer, H.C. Flemming, A.D. Wexler, A. Zwijnenburg, J.C. Kruithof, J.S. Vrouwenvelder, Development and testing of a transparent membrane biofouling monitor, Desal. Wat. Treat., 52 (2014) 1807-1819.

[27] Q. Bu-Ali, M. Al-Aseeri, N. Al-Bastaki, An experimental study of performance parameters and ion concentration along a reverse osmosis membrane, Chem. Eng. Process., 46 (2007) 323-328.

[28] J.S. Vrouwenvelder, S.M. Bakker, M. Cauchard, R. Le Grand, M. Apacandie, M. Idrissi, S. Lagrave, L.P. Wessels, J.A.M. van Paassen, J.C. Kruithof, M.C.M. van Loosdrecht, The membrane fouling simulator: a suitable tool for prediction and characterisation of membrane fouling, Water Sci. Technol., 55 (2007) 197-205.

[29] W.A.M. Hijnen, E.R. Cornelissen, D. van der Kooij, Threshold concentrations of biomass and iron for pressure drop increase in spiral-wound membrane elements, Water Res., 45 (2011) 1607-1616.

[30] K.L. Tu, A.R. Chivas, L.D. Nghiem, Effects of chemical preservation on flux and solute rejection by reverse osmosis membranes, J. Membr. Sci., 472 (2014) 202-209.
[31] J.S. Vrouwenvelder, C. Hinrichs, W.G.J. Van der Meer, M.C.M Van Loosdrecht, J.C. Kruithof, Pressure drop increase by biofilm accumulation in spiral wound $\mathrm{RO}$ and NF membrane systems: role of substrate concentration, flow velocity, substrate load and flow direction, Biofouling, 25 (2009) 543-555.

[32] V.V. Ranade, A. Kumar, Fluid dynamics of spacer filled rectangular and curvilinear channels, J. Membr. Sci., 271 (2006) $1-15$.

[33] I. Lomax, Experiences of Dow in the field of seawater reverse osmosis, Desalination, 224 (2008) 111-118.

[34] G. Schock, A. Miquel, Mass-transfer and pressure loss in spiral wound modules, Desalination, 64 (1987) 339-352.

[35] L.F. Greenlee, D.F. Lawler, B.D. Freeman, B. Marrot, P. Moulin Reverse osmosis desalination: water sources, technology, and today's challenges, Water Res., 43 (2009) 2317-2348.

[36] M. Wilf, The Guidebook to Membrane Desalination Technology: Reverse Osmosis, Nanofiltration and Hybrid Systems, Process, Design, Applications and Economics, Balaban Desalination Publications, L'Aquila, Italy, 2007.

[37] S.S. Bucs, R.V. Linares, M.C.M. van Loosdrecht, J.C. Kruithof, J.S. Vrouwenvelder, Impact of organic nutrient load on biomass accumulation, feed channel pressure drop increase and permeate flux decline in membrane systems, Water Res., 67 (2014) 227-242

[38] A. Magic-Knezev, D. van der Kooij, Optimisation and significance of ATP analysis for measuring active biomass in granular activated carbon filters used in water treatment, Water Res., 38 (2004) 3971-3979.

[39] J.S. Vrouwenvelder, S.A. Manolarakis, J.P. van der Hoek, J.A.M. van Paassen, W.G.J. van der Meer, J.M.C. van Agtmaal, H.D.M Prummel, J.C. Kruithof, M.C.M. van Loosdrecht, Quantitative biofouling diagnosis in full scale nanofiltration and reverse osmosis installations, Water Res., 42 (2008) 4856-4868.

[40] D. Van Gauwbergen, J. Baeyens, Macroscopic fluid flow conditions in spiral-wound membrane elements, Desalination, 110 (1997) 287-299.

[41] S.A. Huber, A. Balz, M. Abert, W. Pronk, Characterisation of aquatic humic and non-humic matter with size-exclusion chromatography - organic carbon detection - organic nitrogen detection (LC-OCD-OND), Water Res., 45 (2011) 879-885.

[42] C. Dreszer, J.S. Vrouwenvelder, A.H. Paulitsch-Fuchs, A Zwijnenburg, J.C. Kruithof, H.C. Flemming, Hydraulic resistance of biofilms, J. Membr. Sci., 429 (2013) 436-447.

[43] D.J. Miller, P.A. Araujo, P.B. Correia, M.M. Ramsey, J.C. Kruithof, M.C.M. van Loosdrecht, B.D. Freeman, D.R. Paul, M. Whiteley, J.S. Vrouwenvelder, Short-term adhesion and long-term biofouling testing of polydopamine and poly(ethylene glycol) surface modifications of membranes and feed spacers for biofouling control, Water Res., 46 (2012) 3737-3753.

[44] A. Subramani, E.M.V. Hoek, Direct observation of initial microbial deposition onto reverse osmosis and nanofiltration membranes, J. Membr. Sci., 319 (2008) 111-125.

[45] M.A. Saad, Biofouling prevention in RO polymeric membrane systems, Desalination, 88 (1992) 85-105.

[46] J. Gutman, S. Fox, J. Gilron, Interactions between biofilms and $\mathrm{NF} / \mathrm{RO}$ flux and their implications for control - a review of recent developments, J. Membr. Sci., 421 (2012) 1-7. 


\section{Supplementary material}

\section{Description of the system and components of the LCMTC}

Each test cell consists of the equipment and materials listed in Table S1. Fig. S1 shows the connection of the devices and components.

\section{Dimensioning of the LCMTC and mechanical stability}

The requirements for the LCMTC were:

- Chemical and mechanical stability

- Applicable for high pressure membrane applications

- Industrial scale dimension

- Visualizing the flow process

Only two serious options for material choice could be named: either the test cell would be made of PMMA (acrylic glass) or stainless steel. PMMA was the choice for us, especially because of the window. Stainless steel is also possible, with good material strength for high pressures. However, stainless steel plates would create a huge weight of the lids.

Choosing PMMA as a plate material, several requirements regarding inner forces needed to be taken into account:

- PMMA has quite a good bending strength. With a given thickness it is stable for high pressures. With a 2-D calculation of a 70 bar pressure case (seawater desalination) in a $40 \mathrm{~mm}$ wide channel it was calculated, that, using a safety factor of 3 , the thickness of the PMMA lid must be $40 \mathrm{~mm}$. Table S2 gives further safety factors for applied system pressures.
- 52 screws have to be tightened to distribute the forces, in order to close the plates with the sealing properly. Stainless steel screws M12 (strength category 8.8) were chosen guaranteeing a proper safety factor.

A model calculation of the equivalent stress (calculated after von Mises yield criterion) was done under the condition of prestressing force of the screws and applied system pressure. It showed that the system would stand pressures up to 70 bar (Fig. S2). In order to take into account that the inlet pipe system pressures of up to 40 bar can be applied.

- The force from the screws, keeping the system closed, is limited by the compressive strength of PMMA. The metal frames on the test cell spread the forces equally and furthermore prevent bending of the PMMA plates and enlarging of the channel when applying higher system pressures.

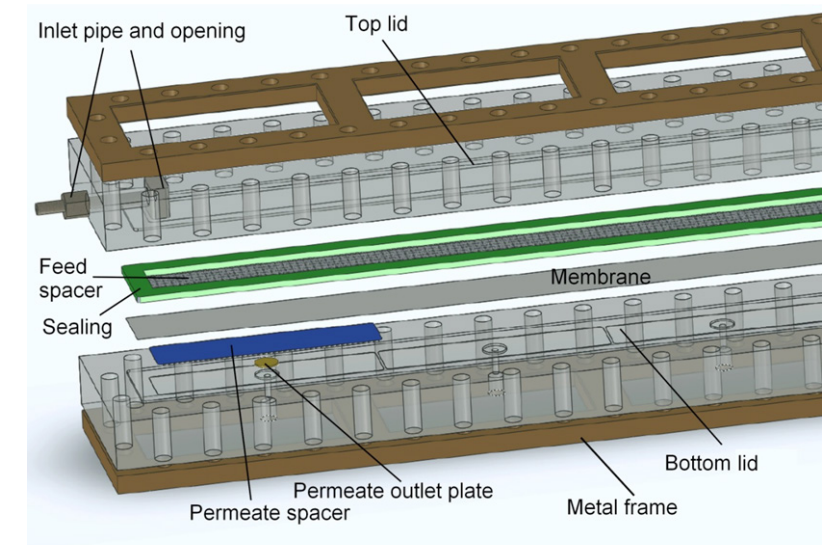

Fig. S1. Composition of the LCMTC and its components.

Table S1

Equipment and components of the LCMTC

\begin{tabular}{lllc}
\hline No. & Component & Material/remarks & Quantity \\
\hline 1 & Bottom lid & PMMA, see Fig. S3 & 1 \\
2 & Top lid & PMMA, see Fig. S4 & 1 \\
3 & Metal frame & Stainless steel, see Fig. S5 & 2 \\
4 & Inlet opening & Stainless steel, see Fig. S6 & 2 \\
5 & Inlet pipe & Stainless steel, see Fig. S7 & 2 \\
6 & Sealing & Aramid yarn, see Fig. S8 & 1 \\
7 & Permeate outlet porous plate & Stainless steel, $20 \mu$ m pore size $19.05 \times 1.57(\mathrm{R} \times \mathrm{H} / \mathrm{mm})$ & 5 \\
8 & Permeate spacer & As delivered from manufacturer, $40 \times 180 / / 181 \times 0.3(\mathrm{~W} \times \mathrm{L} \times \mathrm{H} / \mathrm{mm})$ & 5 \\
9 & Feed spacer & As delivered from manufacturer $40 \times 910 \times 0.787(\mathrm{~W} \times \mathrm{L} \times \mathrm{H} / \mathrm{mm})$ & 1 \\
10 & Connectors for feed pipe/ & Stainless steel - pipe coupling, polyvinylidene fluoride $(\mathrm{PVDF})-\mathrm{hose}$ & $2 / 5$ \\
& permeate tubes & connection & 44 \\
11 & Screws & Stainless steel, M12 (strength category 8.8$)$ & 8 \\
12 & Threaded rod & Stainless steel, M12 (strength category 8.8$)$ & 104 \\
14 & Plain washer & Stainless steel & 64 \\
\hline
\end{tabular}


Table S2

Conditions: flat sealing Klinger C4400 $1 \mathrm{~mm}$; maximum pressure resistance of PMMA: $70 \mathrm{~N} \mathrm{~mm}^{-2}$; screws: M12; 8.8 stainless steel, overlapping area of the sealing by two neighboring screws; temperature $23^{\circ} \mathrm{C}$

\begin{tabular}{llll}
\hline $\begin{array}{l}\text { Applied system pressure } \\
\text { (bar) }\end{array}$ & $\begin{array}{l}\text { Required }{ }^{a} \text { pressure sealing } \\
\left(\mathrm{N} \mathrm{mm}^{-2}\right)\end{array}$ & $\begin{array}{l}\text { Required torque } \\
(\mathrm{Nm})\end{array}$ & $\begin{array}{l}\text { Resulting safety factor for } \\
\text { PMMA }\end{array}$ \\
\hline 10 & 11 & 14 & 5 \\
20 & 20 & 25 & 2.8 \\
30 & 26 & 32 & 2.1 \\
40 & 33 & 41 & 1.7 \\
50 & 44 & 55 & 1.3 \\
60 & 51 & 64 & 1.1 \\
\hline
\end{tabular}

${ }^{\mathrm{a} C a l c u l a t e d}$ by using the software KLINGER ${ }^{\circledR}$ expert provided by the sealing manufacturer (Klinger, Germany).

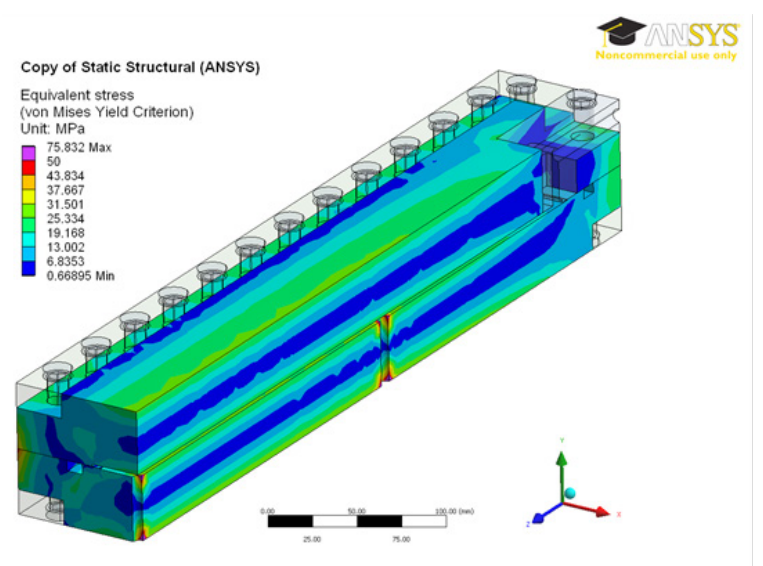

Fig. S2. Structural calculation of the strength within the LCMTC under force influence.

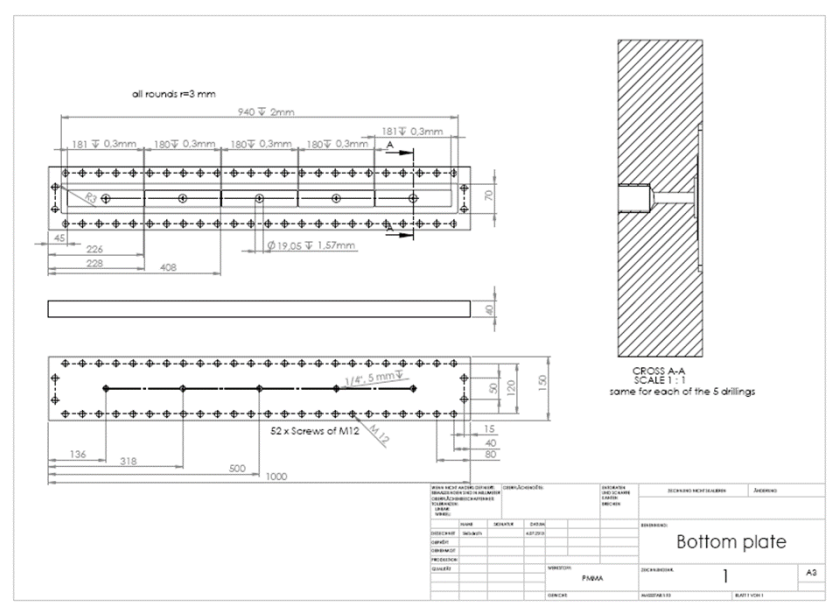

Fig. S3. Bottom plate.

The test cell is sealed with a flat sealing, as most feasible choice. The compression of the sealing can be determined; the height of the sealing contributes to the channel height of the feed channel.

The channel height of the top plate is $0.3 \mathrm{~mm}$. Additionally, the height of the sealing minus its compaction

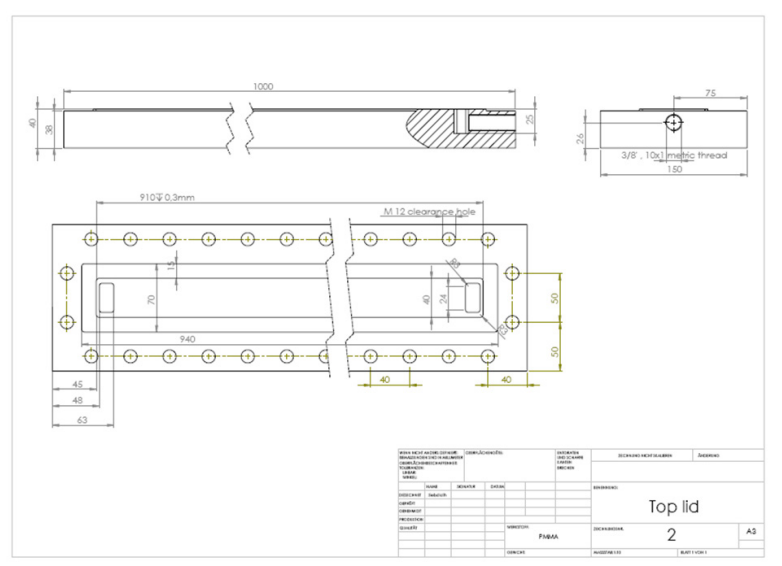

Fig. S4. Top lid.

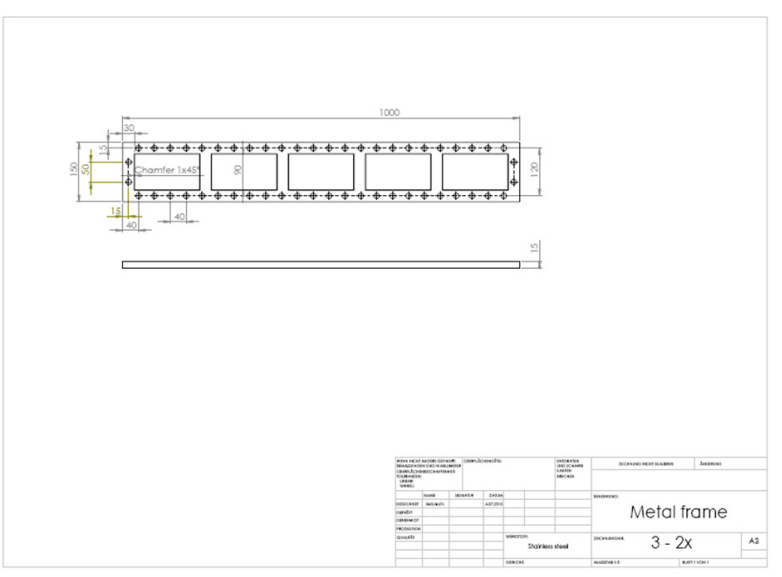

Fig. S5. Metal frame.

has to be considered. We chose a flat sealing of $0.5 \mathrm{~mm}$, with a compaction of $\sim 10 \%(=0.05 \mathrm{~mm})$ under the chosen conditions, resulting in $0.337 \mathrm{~mm}+0.5 \mathrm{~mm}-0.05 \mathrm{~mm}=0.787 \mathrm{~mm}$ height of the feed channel.

The use of other flat sealings gives possibilities to use spacers of different heights. 


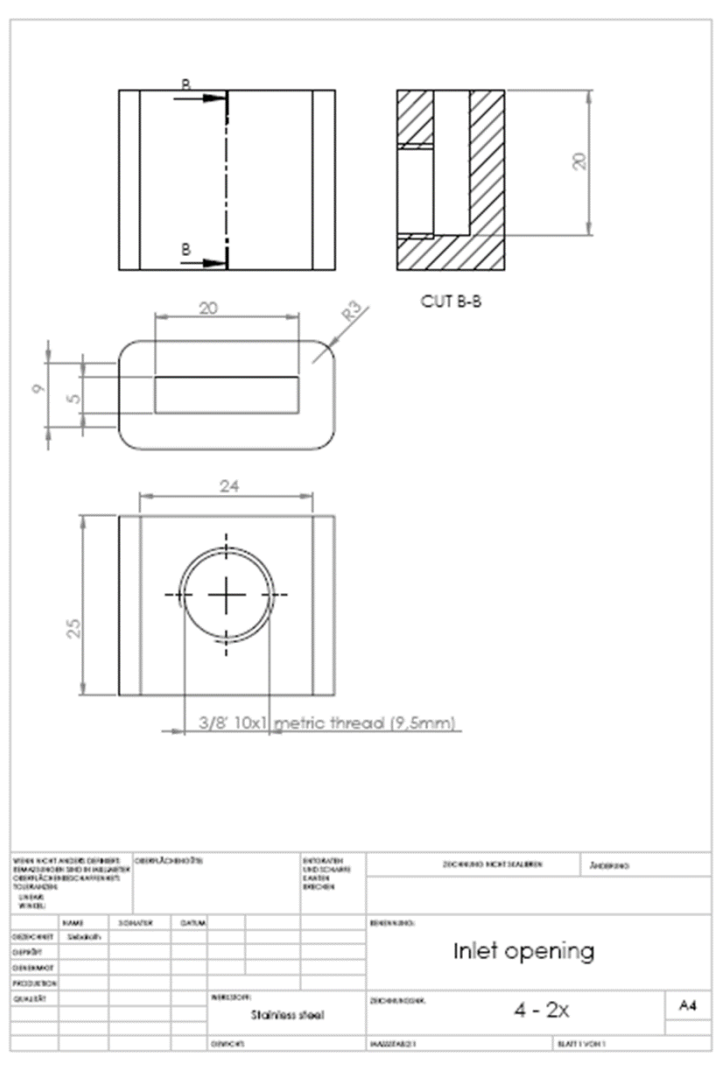

Fig. S6. Inlet opening.

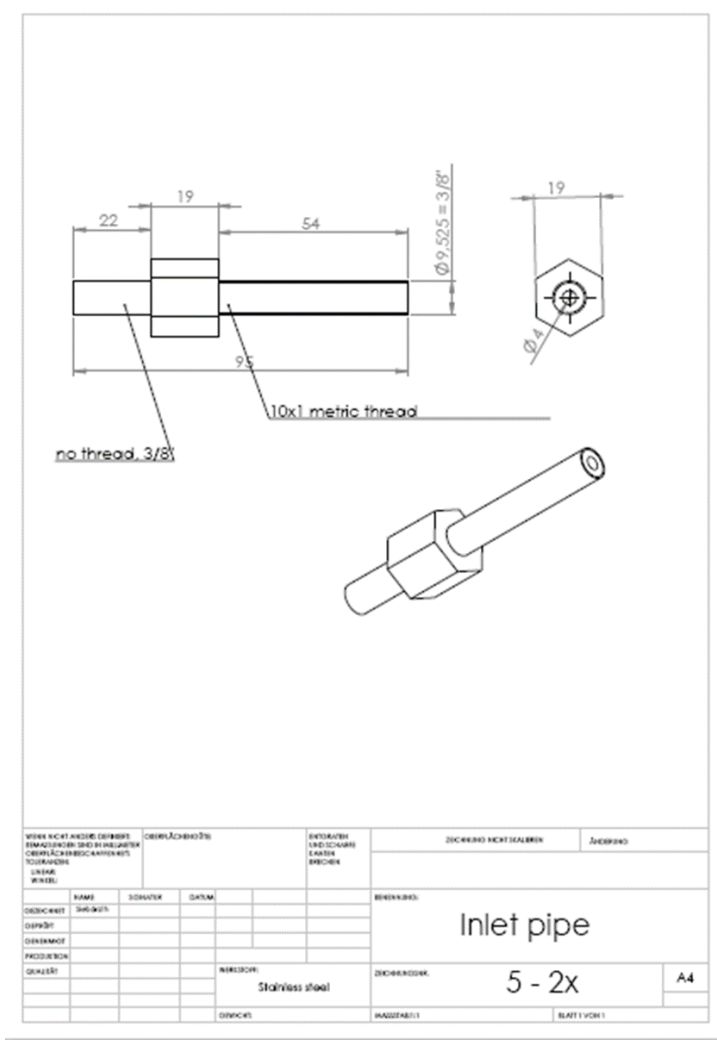

Fig. S7. Inlet pipe.

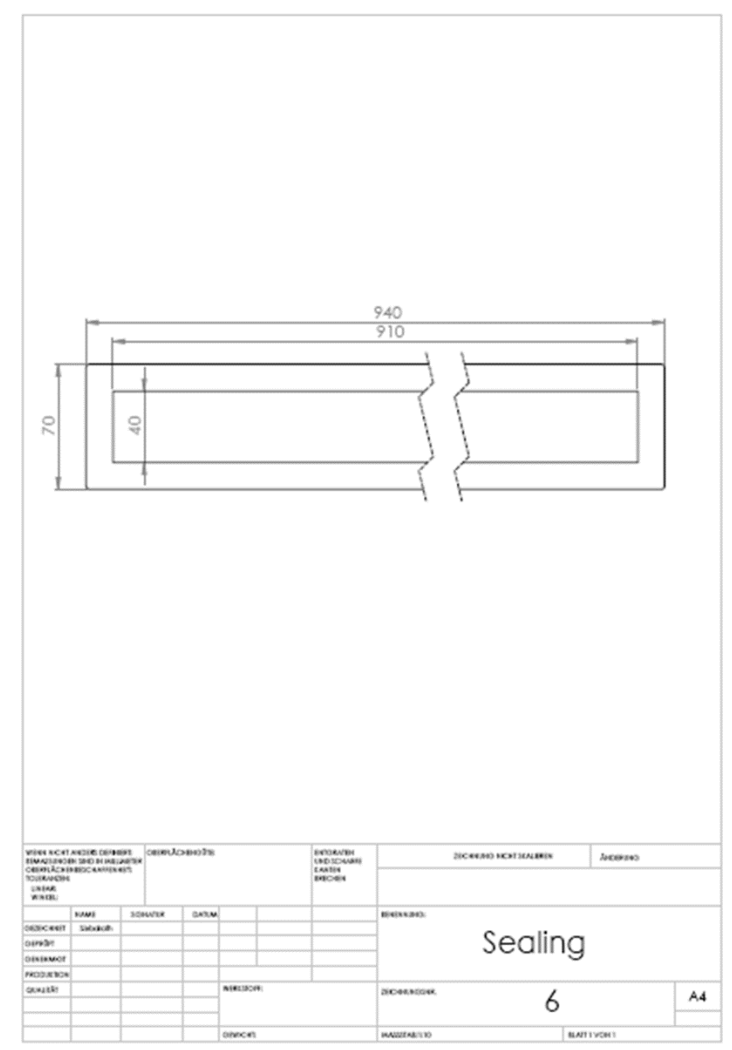

Fig. S8. Sealing.

- The stability of PMMA is dependent on temperature. Above $70^{\circ} \mathrm{C}$ the stability of PMMA decreases by $50 \%$ compared with the stability at $25^{\circ} \mathrm{C}$. This influences the maximum pressure stability and pressing forces onto the cell (see material data sheets of PMMA). When operating at high temperatures, the decreasing material strength has to be taken into account.

\section{Implementing of the LCMTC}

\subsection{Installation}

The test cell should carefully be balanced and fixed on a steady stand. Inserting permeate spacer in the designated permeate segments needs to be done carefully, avoiding any overlapping. Membrane should be cut in the size of $50 \mathrm{~mm}$ $\times 920 \mathrm{~mm}$ being slightly bigger than the sealing to avoid any leakage. Feed spacer should fit exactly in the sealing's recess on top of the membrane.

\subsection{Closing of the test cells}

The test cell needs to be closed precisely. It is advised to tighten the screws in crosswise direction starting from the center to ensure properly distributed compaction of the sealing.

For the stated components, material specifications, geometries and forces the maximum acceptable torsional moment for a save closing of the test cell was calculated and is also given in Table S2. 


\section{Development of the fouling layer resistance}

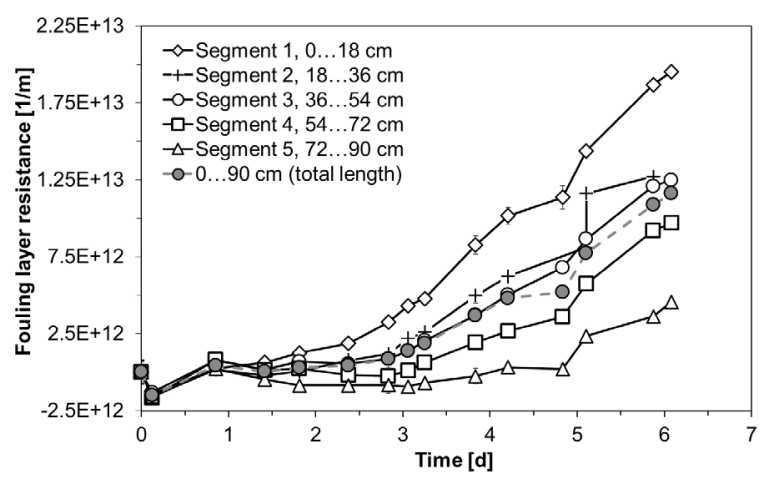

Fig. S9. Development of the total (transmembrane) fouling layer resistance with time over the length of the membrane test cell. 